\title{
Research on shearing performance of asphalt mixture with Lucobit
}

\author{
Yemao Zhang ${ }^{1,3, \text { a }}$, Mulian Zheng ${ }^{2, b}$, Juan Chen ${ }^{3, c}$ \\ ${ }^{1}$ Key Laboratory for Special Area Highway Engineering of Ministry of Education,Chang'an \\ University, Xi'an Shan Xi 710064,China \\ ${ }^{2}$ Key Laboratory for Special Area Highway Engineering of Ministry of Education,Chang'an \\ University, Xi'an Shan Xi 710064,China \\ ${ }^{3}$ Jiang Su Provincial Communication Planning and Design Institute CO.LTD,9 Ziyun Street,Nanjing, \\ 210014 P.R. China

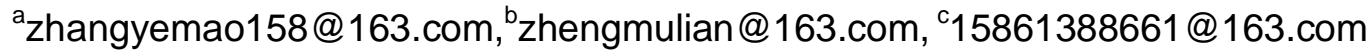

Keywords: Lucobit modifier; Shearing Performance; Uniaxial penetration test

Abstract. To study the shearing performance of asphalt mixture with Lucobit, AC-13C and SUP-20 asphalt mixture with Lucobit were carried out the uniaxial penetration test and the direct shear test. The results show that the angle of internal friction of the same gradation and temperature has little difference, cohesion force of the same asphalt decrease with the rising of temperature at the same graduation, and Lucobit modifier can greatly improve the shearing performance of asphalt mixture for both AC-13C and SUP-20.

\section{Introduction}

The Lucobit modified agent is developed and applied for patent by German Basifu chemical industry group in 1966. The company of Lucobit has exclusive rights to produce a kind of polymer which is made up of the mixture of high quality polyethylene copolymer and a special kind of asphalt $(\mathrm{ECB})^{[1-3]}$. Asphalt mixture with Lucobit can improve coated force and plastic deformation capability of the asphalt, reduce the dosage of asphalt, and improve the stability of asphalt mixture under heat and pressure. To study the shearing performance of mixture with Lucobit of different asphalt binder, the asphalt mixture with the grading of AC-13C and SUP-20,the binder of 70\#+0.4\%PR, 70\#+0.5\% Lufu8000, 70\#+7\% Lucobit, SBS and 50\# gilsonite were selected to make the uniaxial penetration test and direct shear test.

\section{Contrastive analysis on the uniaxial penetration test results}

The asphalt mixture with the grading of AC-13C and SUP-20,the binder of 70\#+0.4\%PR, 70\#+0.5\% Lufu8000, 70\#+7\% Lucobit, SBS and 50\# gilsonite were selected to make the uniaxial penetration test on $60^{\circ} \mathrm{C}$ and $70^{\circ} \mathrm{C}$. Test results of the uniaxial penetration are shown in table1and table 2. 
Table $160^{\circ} \mathrm{C}$ uniaxial penetration test results of asphalt mixture with different asphalt

\begin{tabular}{|c|c|c|c|c|c|c|c|c|}
\hline & \multirow[b]{2}{*}{ Mixture type } & \multicolumn{2}{|c|}{ Penetration test } & \multicolumn{2}{|c|}{ Unconfined compression test } & \multirow{2}{*}{$\begin{array}{c}\tau_{\max } \\
(\mathrm{MPa})\end{array}$} & \multirow{2}{*}{$\begin{array}{l}\Phi \\
\left({ }^{\circ}\right)\end{array}$} & \multirow{2}{*}{$\begin{array}{c}\mathrm{C} \\
(\mathrm{MPa})\end{array}$} \\
\hline & & $\begin{array}{l}\text { Stress } \\
(\mathrm{MPa})\end{array}$ & $\begin{array}{l}\text { Deformation } \\
\quad(\mathrm{mm})\end{array}$ & $\begin{array}{l}\text { Stress } \\
(\mathrm{MPa})\end{array}$ & $\begin{array}{l}\text { Deformation } \\
\quad(\mathrm{mm})\end{array}$ & & & \\
\hline \multirow{5}{*}{ AC-13C } & $70 \#$ with $0.4 \% \mathrm{PR}$ & 3.6622 & 1.5007 & 1.5163 & 1.9922 & 1.2415 & 37.0112 & 0.3779 \\
\hline & 70\# with 7\%Lucobit & 4.0129 & 1.3841 & 1.6064 & 1.8842 & 1.3604 & 37.8841 & 0.3928 \\
\hline & 70\# with $0.5 \%$ Lufu 8000 & 3.4315 & 1.5228 & 1.4422 & 1.9842 & 1.1633 & 36.5996 & 0.3627 \\
\hline & SBS modified & 2.8125 & 1.1349 & 1.1763 & 1.7722 & 0.9534 & 36.7360 & 0.2949 \\
\hline & 50\# gilsonite & 2.6248 & 1.1184 & 1.0723 & 1.647 & 0.8898 & 37.3670 & 0.2652 \\
\hline \multirow{5}{*}{ SUP-20 } & 70\# with $0.4 \% \mathrm{PR}$ & 3.6741 & 1.5523 & 1.5226 & 1.9054 & 1.2455 & 36.9868 & 0.3797 \\
\hline & 70\# with 7\% Lucobit & 4.3806 & 1.5762 & 1.7498 & 2.1142 & 1.4850 & 37.9381 & 0.4273 \\
\hline & 70\# with $0.5 \%$ Lufu 8000 & 3.4521 & 1.7112 & 1.4613 & 2.0016 & 1.1703 & 36.3966 & 0.3691 \\
\hline & SBS modified & 2.9042 & 1.7212 & 1.1906 & 2.1348 & 0.9845 & 37.2751 & 0.2950 \\
\hline & 50\# gilsonite & 2.6475 & 1.2111 & 1.1140 & 1.7112 & 0.8975 & 36.5668 & 0.2803 \\
\hline
\end{tabular}

Table $270^{\circ} \mathrm{C}$ uniaxial penetration test results of asphalt mixture with different asphalt

\begin{tabular}{|c|c|c|c|c|c|c|c|c|}
\hline & \multirow[b]{2}{*}{ Mixture type } & \multicolumn{2}{|c|}{ Penetration test } & \multicolumn{2}{|c|}{ Unconfined compression test } & \multirow{2}{*}{$\begin{array}{c}\tau_{\max } \\
(\mathrm{MPa})\end{array}$} & \multirow{2}{*}{$\begin{array}{c}\Phi \\
\left({ }^{\circ}\right)\end{array}$} & \multirow{2}{*}{$\begin{array}{c}\mathrm{C} \\
(\mathrm{MPa})\end{array}$} \\
\hline & & $\begin{array}{l}\text { Stress } \\
(\mathrm{MPa})\end{array}$ & $\begin{array}{l}\text { Deformation } \\
(\mathrm{mm})\end{array}$ & $\begin{array}{l}\text { Stress } \\
(\mathrm{MPa})\end{array}$ & $\begin{array}{l}\text { Deformation } \\
(\mathrm{mm})\end{array}$ & & & \\
\hline \multirow{5}{*}{ AC-13C } & $70 \#$ with $0.4 \% \mathrm{PR}$ & 1.5220 & 1.7244 & 0.6748 & 2.5540 & 0.5160 & 34.9893 & 0.1757 \\
\hline & 70\# with 7\%Lucobit & 1.6721 & 1.7067 & 0.7538 & 2.5248 & 0.5668 & 34.4377 & 0.1986 \\
\hline & $70 \#$ with $0.5 \%$ Lufu 8000 & 1.5043 & 1.8172 & 0.6451 & 2.5433 & 0.5100 & 36.0195 & 0.1643 \\
\hline & SBS modified & 1.1719 & 1.3993 & 0.5199 & 2.3747 & 0.3973 & 34.9686 & 0.1354 \\
\hline & 50\# gilsonite & 0.9847 & 1.2916 & 0.4416 & 2.4746 & 0.3338 & 34.6135 & 0.1159 \\
\hline \multirow{5}{*}{ SUP-20 } & $70 \#$ with $0.4 \%$ PR & 1.5883 & 1.9142 & 0.7133 & 2.6669 & 0.5384 & 34.5661 & 0.1874 \\
\hline & 70\# with 7\%Lucobit & 1.8223 & 1.9435 & 0.8457 & 2.8330 & 0.6178 & 33.4125 & 0.2276 \\
\hline & $70 \#$ with $0.5 \%$ Lufu 8000 & 1.5114 & 1.9766 & 0.6558 & 2.7944 & 0.5124 & 35.6669 & 0.1683 \\
\hline & SBS modified & 1.2577 & 1.5084 & 0.5414 & 2.4719 & 0.4264 & 35.9067 & 0.1382 \\
\hline & 50\# gilsonite & 0.9972 & 1.5542 & 0.4327 & 2.5042 & 0.3381 & 35.6660 & 0.1110 \\
\hline
\end{tabular}

Table1 and Table2 show that, the angle of internal friction of the same gradation and temperature has little difference. The reason is the gradation of the mixture playing a decisive role in the angle of internal friction at the same temperature. The angle of internal friction has little difference at the same grading ${ }^{[4,5]}$.

Cohesion force of the same asphalt decrease with the rising of temperature at the same graduation. The asphalt binder of the mixture play a decisive role in the cohesion force at the same grading. The greater cohesive force show that the stronger bonding performance of the asphalt binder. At the same gradation and temperature, the size order of cohesive force is $70 \#$ with $7 \%$ Lucobit>70\# with $0.4 \%$ PR $>70 \#$ with $0.5 \%$ Lufu8000>SBS modified asphalt mixture>50\# gilsonite. 
The shearing strength $\tau \max$ decrease with the rise of the temperature of the mixture at the same grading and asphalt binder, the cohesion force of the asphalt binder play a decisive role in the shearing strength at the same grading and temperature. The greater cohesive force show that the stronger shearing strength of the asphalt binder. At the same gradation, the size order of shear strength is $70 \#$ with $7 \%$ Lucobit $>70 \#$ with $0.4 \%$ PR $>70 \#$ with $0.5 \%$ Lufu8000>SBS modified asphalt mixture $>50 \#$ gilsonite.

\section{Contrastive analysis on the direct shear results}

The asphalt mixture with the grading of AC-13C and SUP-20,the binder of 70\#+0.4\%PR, $70 \#+0.5 \%$ Lufu8000, 70\#+7\% Lucobit, SBS and 50\# gilsonite were selected to make the direct shear test on $60^{\circ} \mathrm{C}$ and $70^{\circ} \mathrm{C}$. Test results of the uniaxial penetration are shown in table3.

Table 3 Direct shear test results of asphalt mixture with different asphalt

\begin{tabular}{|c|c|c|c|}
\hline & Mixture type & $60^{\circ} \mathrm{C}$ shear strength $(\mathrm{MPa})$ & $70^{\circ} \mathrm{C}$ shear strength $(\mathrm{MPa})$ \\
\hline \multirow{5}{*}{$\mathrm{AC}-13 \mathrm{C}$} & $70 \#$ with $0.4 \% \mathrm{PR}$ & 1.0316 & 0.3316 \\
\hline & 70\# with 7\% Lucobit & 1.1455 & 0.3638 \\
\hline & 70\# with $0.5 \%$ Lufu8000 & 0.9844 & 0.3006 \\
\hline & SBS modified & 0.7536 & 0.1876 \\
\hline & 50\# gilsonite & 0.5142 & 0.1124 \\
\hline \multirow{5}{*}{ SUP-20 } & 70\# with $0.4 \% \mathrm{PR}$ & 1.1144 & 0.3384 \\
\hline & 70\# with 7\% Lucobit & 1.2355 & 0.4178 \\
\hline & 70\# with $0.5 \%$ Lufu8000 & 1.0811 & 0.322 \\
\hline & SBS modified & 0.8834 & 0.2122 \\
\hline & 50\# gilsonite & 0.5227 & 0.1216 \\
\hline
\end{tabular}

Table 3 shows that, the direct shear strength decrease with the rising of the temperature. The size order of direct shear strength at the same gradation and temperature is 70\# with $7 \%$ Lucobit>70\# with $0.4 \%$ PR $>70 \#$ with $0.5 \%$ Lufu8000>SBS modified asphalt mixture $>50 \#$ gilsonite.

\section{Conclusions}

(1) The angle of internal friction of the same gradation and temperature has little difference.

(2) At the same gradation and temperature, the size order of cohesive forc and shearing strength is 70\# with 7\% Lucobit>70\# with $0.4 \%$ PR $>70 \#$ with $0.5 \%$ Lufu8000>SBS modified asphalt mixture $>50 \#$ gilsonite.

(3) The size order of direct shear strength at the same gradation and temperature is 70\# with $7 \%$ Lucobit>70\# with $0.4 \%$ PR $>70 \#$ with $0.5 \%$ Lufu8000>SBS modified asphalt mixture>50\# gilsonite.

(4) Lucobit modifier can greatly improve the shearing performance of asphalt mixture for both AC-13C and SUP-20. 


\section{References}

[1] Liu Li, Chen Ji-ming, Kan Wen-tao. Research on pavement performance of Lucobit 1210A[J]. The Chinese and foreign road, 2012, 32(6):290-293.

[2] Kong Zhi-gang. New type of modified asphalt additives Lucobit 1210A[J]. Traffic world, 2008(17):104-105.

[3] Khaki A M, Baladehi S H S, Akbari T, et al. The Investigation of the Impact of Lucobit Polymer on Bitumen Performance[J]. Article Author (s) page, 2013: 570.

[4] LOEBER L, MULLER G, MOREL J, et al. Bitumen in colloidal science: a chemical, structural and rheological approach[J]. Fuel, 1998, 77 (3) : 1443 1450.

[5] Ludomir Uzarowski,Golder Associates Ltd, Michel Paradis,Ministere des Transports du Quebec, Quebec Paul Lum, Lafarge Canada Inc. Accelerated Performance Testing Of Canadian Asphalt Mixes Using Three Different Wheel Rut Testers[R]. Quebec City, Quebec, 2004: 3 5. 